\title{
Ultrasound Characterization of Salivary Lesions
}

Rajesh C Kamble, Alpana N Joshi, Pravin J Mestry

\begin{abstract}
Evolution in ultrasound technology leads to birth of high frequency, high resolution linear transducers which in turn revolutionized the imaging of superficial structures. The majority of cases presenting to clinician in day-to-day practice as facial lumps or neck lump could be evaluated using ultrasound and help in imaging of salivary gland lesions. The age of the clinical presentation and morphological characteristics of lesions on ultrasound helped us in making confident diagnosis which was correlated on fine needle aspiration cytology/histopathology studies.
\end{abstract}

Keywords: Salivary glands, Ultrasound, Parotid glands, Submandibular glands, Sialadenitis.

\section{Source of support: Nil}

Conflict of interest: None declared

\section{INTRODUCTION}

The protocol for imaging of salivary glands in Western countries includes-nonenhanced and contrast-enhanced computed tomography (CT), nonenhanced and contrastenhanced magnetic resonance (MR) imaging and sialography (also MR sialography)., ${ }^{1,2}$

In general, CT is considered the best single method for assessment of inflammatory diseases and MR imaging is considered the best single method for assessment of salivary gland tumors. ${ }^{1-3}$ According to Yousem et $\mathrm{al}^{2}$ ultrasonography (US) is not preferred modality in Western countries; but in Europe and Asia, US is widely accepted as the first imaging method for assessment of lymph nodes and soft tissue diseases in the head and neck, including major salivary glands. ${ }^{4-7}$ Infact US with US-guided fine needle aspiration cytology (FNAC) of the lesions examination alone may suggest the final diagnosis in most of the clinical settings.

As the head and neck region has a complex anatomic structure, a sound knowledge of sonographic anatomy and spatial relationships is crucial for reliable performance of the examination.

It is sometimes not possible to visualize and analyze examined lesions completely at US because of their location for example-deep lobe of the parotid gland or area behind the mandible. In these situations, performance of further imaging examinations-CT or MR imaging - is highly recommended. Also, in cases of suspected malignant lesions, further diagnostic methods (i.e. CT or MR imaging) should be applied to assess possible infiltration of bones or deep structures invisible at US (the base of the skull, parapharyngeal space) and to evaluate deep-lying lymph nodes. ${ }^{1,3,8,9}$

On the other hand, dynamic scintigraphy is still the method of choice in functional evaluation of the salivary glands. ${ }^{10,11}$

\section{TECHNIQUE}

The examination should be carried out with the highest frequency transducer possible. Usually, 5 to $12 \mathrm{MHz}$ wideband linear transducers (median frequency: $7-7.5 \mathrm{MHz}$ or more) are used. ${ }^{9}$ In assessment of large tumors and lesions located in deep portions of the glands, 5 to $10 \mathrm{MHz}$ transducers may be useful. ${ }^{12}$ Entire salivary glands and all lesions have to be evaluated in at least two perpendicular planes during a US examination. The whole neck should also be scanned to assess lymph nodes and search for concomitant or related disease.

\section{NORMAL ULTRASOUND ANATOMY OF SALIVARY GLAND}

\section{Parotid Gland}

The parotid gland is located in the retromandibular fossa, anterior to the ear and sternocleidomastoid muscle. Parts of the superficial lobe cover the ramus of the mandible and the posterior part of the masseter muscle. The border between the superficial and deep parotid lobes is created by a plane in which the facial nerve and its branches are located (Figs 1A and B). Branches of the facial nerve are not visible at US. Parts of the trunk of this nerve may be demonstrated only with high frequency probes (above 10 $\mathrm{MHz}){ }^{13}$ Therefore, the retromandibular vein, which usually lies directly above the trunk of the facial nerve, ${ }^{14,15}$ is used as a US landmark separating the superficial and deep lobes of the parotid gland. The deep parotid lobe can be visualized only partially at US.

The echotexture of the major salivary glands, including the parotid gland, is generally homogeneous and hyperechoic in comparison to adjacent muscles. The echogenicity of the parotid gland is based on the amount of intraglandular fatty tissue (Figs 2A and B).

After leaving the parotid gland, the main excretory duct (Stensen's duct) lies on the masseter muscle, about $1 \mathrm{~cm}$ below the zygomatic arch, then crosses the buccal muscle 

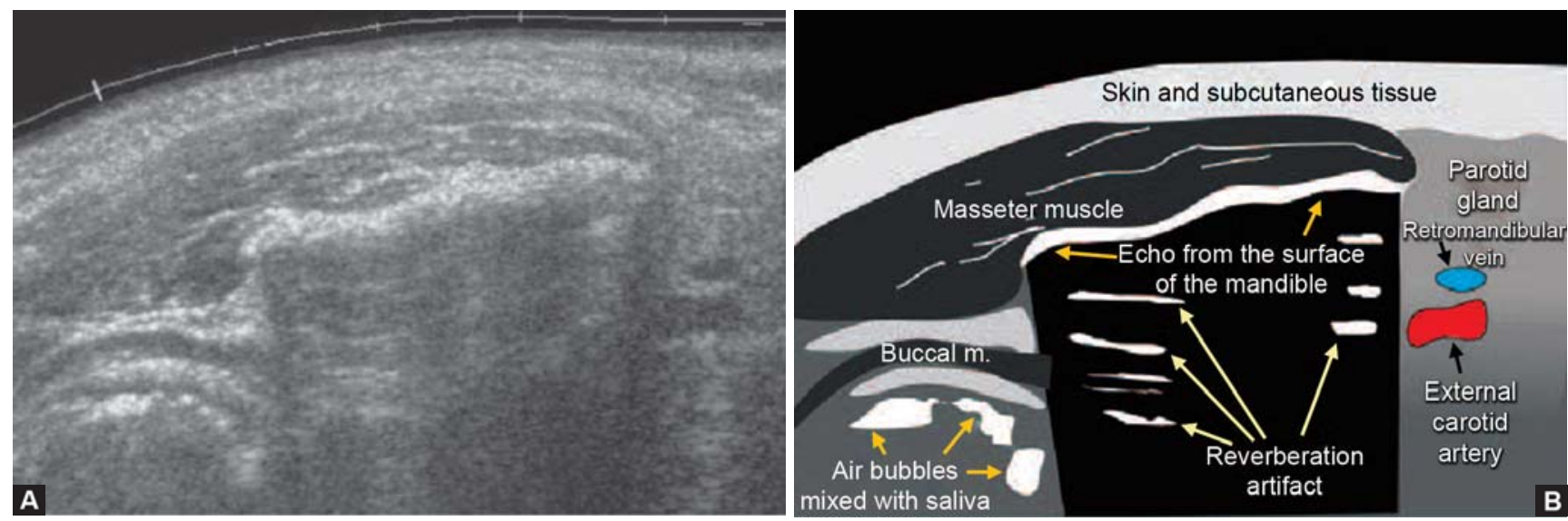

Figs 1A and B: Transverse panoramic US image (A) and corresponding diagram (B) show the normal anatomy of the left parotid gland and part of the cheek
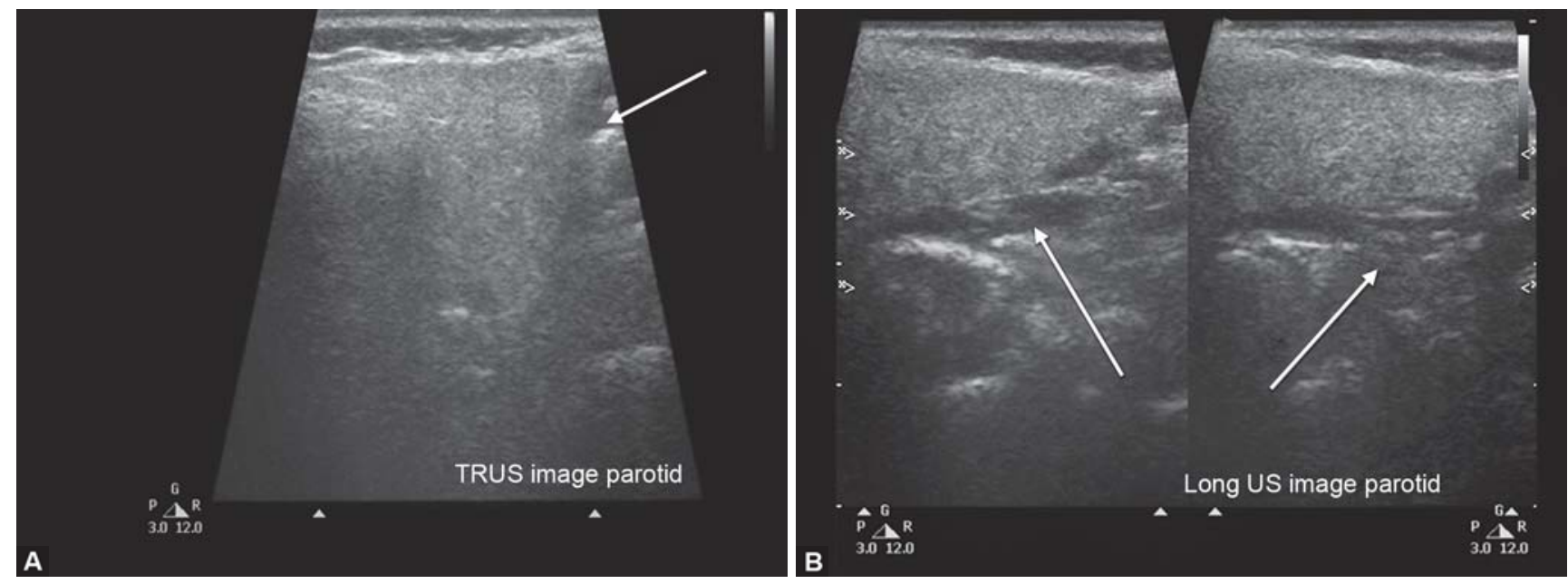

Figs 2A and B: Transverse (A) and longitudinal (B) US images show the normal anatomy of the parotid gland

and has its orifice in the parotid papilla at the level of the upper second molar. The length of the Stensen's duct usually varies between 3 and $5 \mathrm{~cm}$. Along the course of the Stensen's duct in the soft tissues of the cheek, an accessory parotid gland may be found, unilaterally or bilaterally.

The accessory parotid gland may also be the site of salivary gland tumors, benign or malignant. ${ }^{16-18}$

In the parenchyma of the parotid gland, lymph nodes may be found. ${ }^{19}$ They are localized mainly in the area of the upper and lower poles of the gland. Normal intraparotid lymph nodes may be oval or have a longitudinal shape. Almost $60 \%$ of parotid nodes have a short axis-to-long axis ratio greater than 0.5 . A well preserved hyperechoic hilum is one of the important criteria for the normality of parotid lymph nodes. Their short axis should not exceed 5 to $6 \mathrm{~mm}$ in the normal state. ${ }^{6,7}$

\section{Submandibular Gland}

The submandibular gland lies in the posterior part of the submandibular triangle. The sides of the submandibular triangle are created by the anterior and posterior bellies of the digastric muscle and the body of the mandible. The space anterior to the submandibular gland is occupied by connective tissue and lymph nodes. Generally, the shape of the submandibular gland in longitudinal and transverse sections is close to a triangle (Figs $3 \mathrm{~A}$ and $\mathrm{B}$ ).

The submandibular excretory duct (Wharton duct) runs from the area of the submandibular gland hilum at the level of the border of the mylohyoid muscle, then bends around the free part of the mylohyoid muscle and extends to its orifice at the sublingual caruncle along the medial part of the sublingual gland.

\section{Sublingual Gland}

The sublingual gland lies between the muscles of the oral cavity floor: the geniohyoid muscle, intrinsic muscles of the tongue and hyoglossus muscle (medially) and the mylohyoid muscle. Its lateral side is adjacent to the mandible. On transverse sections, the shape of the sublingual gland is close to an oval; on sections parallel to the body of the mandible, the shape is longitudinal and lentiform (Figs 4A and B). 


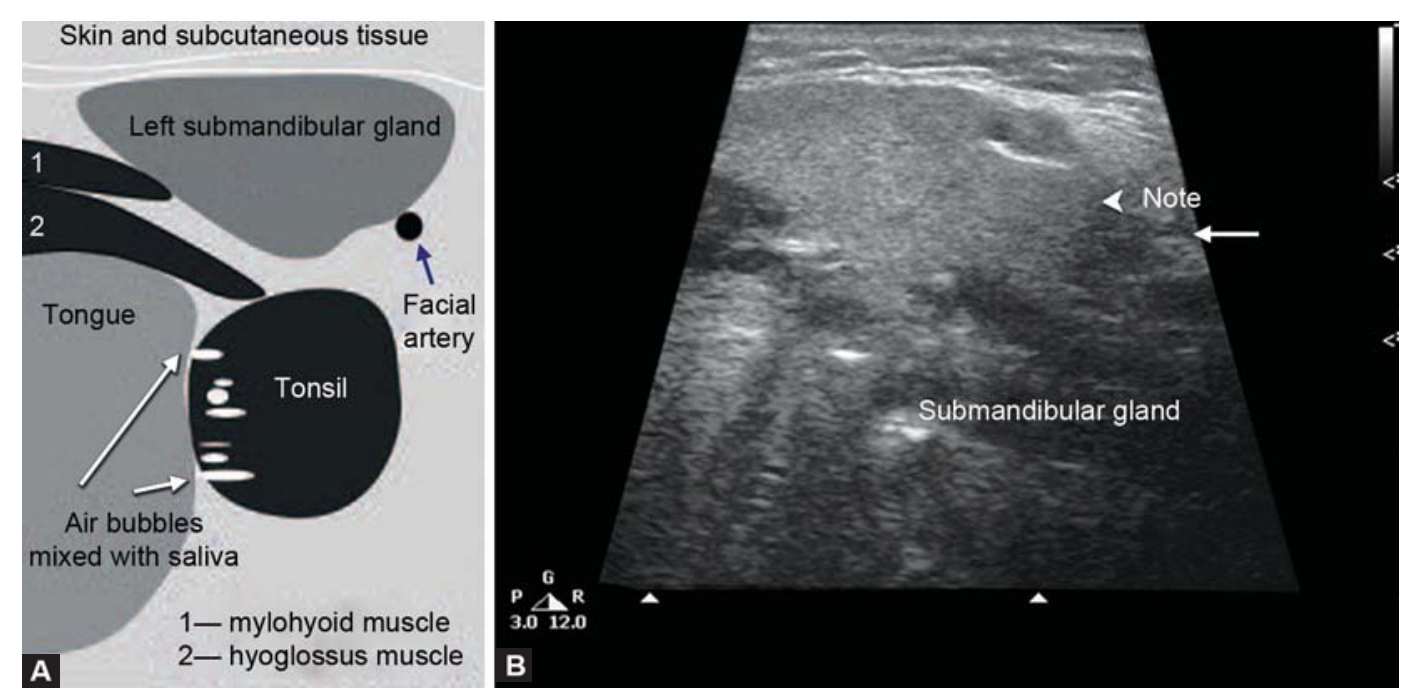

Figs $3 A$ and $B$ : US image $(B)$ and corresponding diagram $(A)$ show the left submandibular gland with surrounding structures

\section{INFLAMMATORY DISEASES}

Inflammatory diseases are the most common diseases affecting the major salivary glands. ${ }^{1,3}$

\section{Acute Inflammation}

Acute inflammation presents clinically as painful swellings of the salivary gland and are often bilateral.

Viral salivary gland infections are the most common in children. A particular predilection for the salivary glands is shown by mumps virus and cytomegalovirus. ${ }^{20}$ Acute bacterial infections are usually caused by Staphylococcus aureus or oral flora. ${ }^{21}$

In acute inflammation, salivary glands are enlarged and hypoechoic. They may be inhomogeneous; may contain multiple small, oval, hypoechoic areas; and show increased vascularity (Fig. 5). ${ }^{9,22-25}$ Enlarged lymph nodes with increased central blood flow may be observed in acute inflammation of salivary glands. ${ }^{26}$

\section{Abscess}

During acute sialadenitis, abscess formation may take place. Predisposing factors include dehydration and excretory duct obstruction caused by stones or fibrosis. ${ }^{27}$ At clinical examination, abscesses may be difficult to detect. They usually manifest as painful swelling of the salivary gland with skin reddening. ${ }^{28}$

At US, abscesses are hypoechoic or anechoic lesions with posterior acoustic enhancement and unclear borders. ${ }^{22,28}$ Central liquefaction maybe distinguished as an avascular area or identified by means of moving debris (Fig. 6). ${ }^{9}$ Organized abscesses may be surrounded by a hyperechoic 'halo'.22 US guidance is helpful for therapeutic drainage..$^{28,29}$
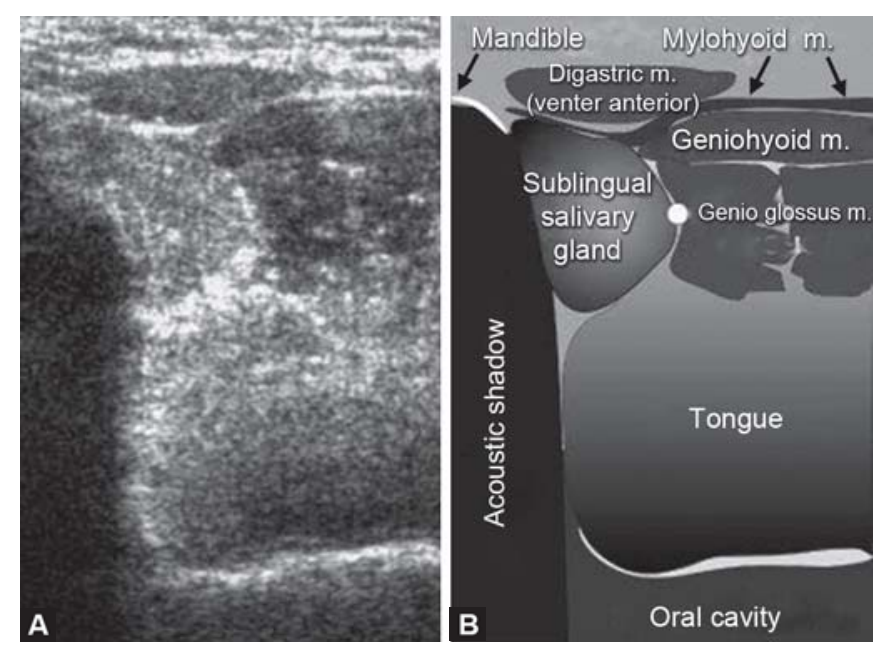

Figs 4A and B: Transverse US image (A) and corresponding diagram (B) show the sublingual gland and its surrounding structures. White circle: Wharton duct; m: muscle

\section{Chronic Sialadenitis}

Chronic sialadenitis is clinically characterized by intermittent swelling of the gland, often painful, that may or may not be associated with food. ${ }^{30}$ In chronic inflammation, salivary glands are normal sized or smaller, hypoechoic, and inhomogeneous and usually do not have increased blood flow at US, , $^{92,24}$

At US, chronic and sometimes acute sialadenitis in children as well as acalculous submandibular gland sialadenitis in adults have also been described as showing multiple small, round or oval, hypoechoic lesions distributed throughout glandular parenchyma. ${ }^{23,25,31}$ The differential diagnosis in such cases includes sarcoidosis and other granulomatous diseases, Sjogren's syndrome, disseminated lymphoma, hematogenous metastases, and benign lymphoepithelial lesions in human immunodeficiency virus (HIV)-positive patients. ${ }^{32-35}$ 

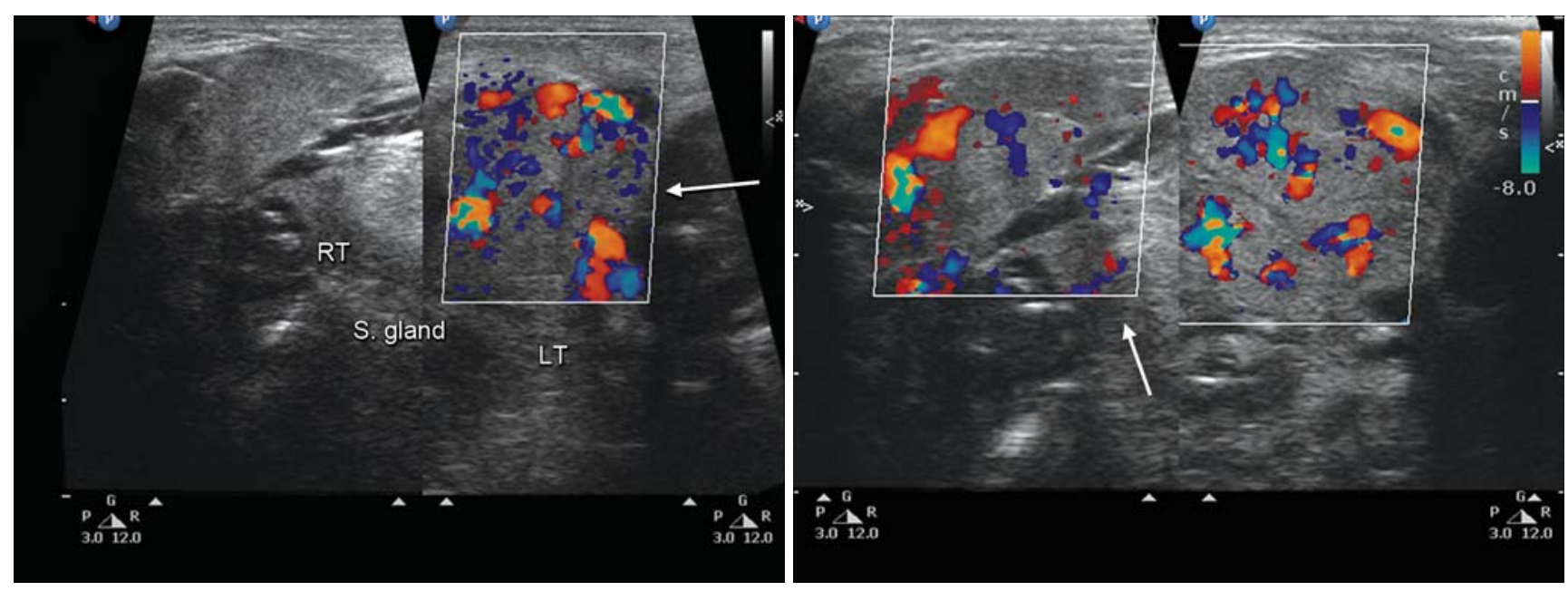

Fig. 5: Color Doppler US image shows an acutely inflamed left submandibular gland (arrows).

The gland is enlarged and hypoechoic and shows increased blood flow

\section{Chronic Sclerosing Sialadenitis}

A special form of chronic sialadenitis that may mimic a malignant lesion, both clinically and at imaging, is chronic sclerosing sialadenitis (Kuttner's tumor). ${ }^{36,37}$ In Kuttner's tumor, diffuse involvement of the salivary gland (usually the submandibular gland) may occur, with multiple small hypoechoic foci scattered on a heterogeneous background of salivary tissue visible at US. ${ }^{36}$ In all doubtful cases, verification with FNA/biopsy is recommended. ${ }^{38,39}$

\section{GRANULOMATOUS SIALADENITIS}

Granulomatous sialadenitis occurrence is rare. ${ }^{20}$ US features of granulomatous sialadenitis are nonspecific: single or multiple hypoechoic areas in an enlarged or normally sized gland or diffuse hypoechoic areas are noted. 9,12,19,40-43

Mycobacterial disease of major salivary glands may manifest as a salivary gland mass, clinically indistinguishable from a neoplasm. ${ }^{44}$ In the parenchymal type of tuberculosis, Chou et $\mathrm{al}^{45}$ described focal, intraparotid, anechoic areas that might have a cavity or cavities within them. In necrotic caseous cavities, which appear very hypoechoic, no color flow can be detected at US, in contrast to most salivary tumors. ${ }^{45}$ Salivary gland actinomycosis may mimic a malignant tumor at US; it may manifest as a hypoechoic area with ill-defined margins. ${ }^{46}$

\section{LYMPH NODES IN SIALADENITIS}

In acute or chronic inflammation, lymph nodes may be enlarged; however, their normal echo structure (homogeneous cortex and hyperechoic central hilum) is preserved.

\section{Sialolithiasis}

Salivary stones are most often located in the submandibular gland (60-90\% of cases) and may be multiple. ${ }^{47-50}$ Parotid

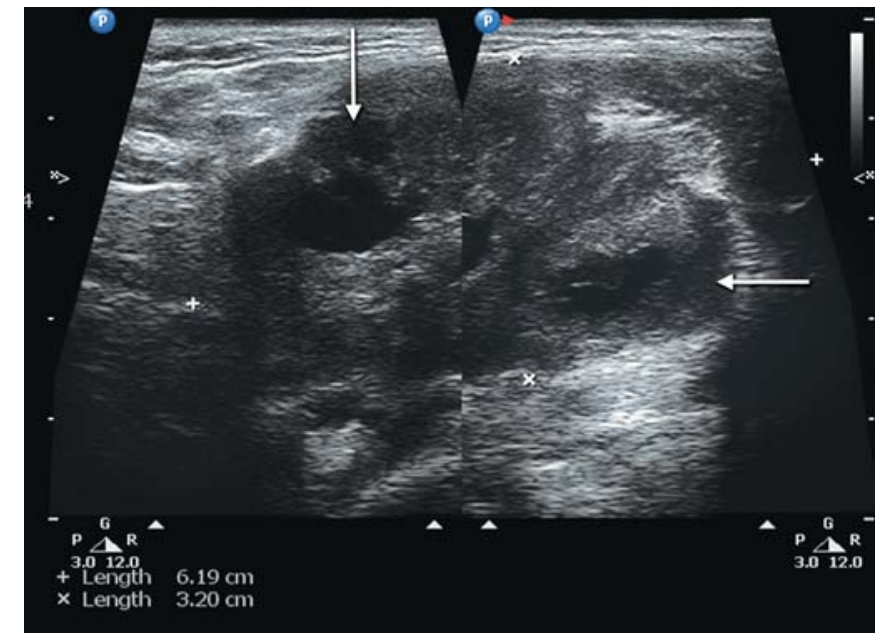

Fig. 6: B-mode US image shows an enlarged parotid gland with areas of necrosis (arrows) suggestive of an early abscess formation

glands are affected in about 10 to $20 \%$ of cases. ${ }^{51}$ On classic radiographs, intraglandular and small stones may be missed, and only about $20 \%$ of sialoliths are radiopaque. ${ }^{52} \mathrm{CT}$ allows visualization of large stones but without their precise localization and without the possibility of assessment of the ducts. ${ }^{53}$

The standard technique for imaging of the submandibular duct and the intraglandular ductal system remains digital sialography. ${ }^{54} \mathrm{~A}$ novel, noninvasive, promising method appears to be MR sialography, which also gives very good results in detection of sialoliths. ${ }^{2,54,55}$

US is a noninvasive method, well-established in cases of clinical suspicion of sialolithiasis, and is used as a primary modality, particularly in Europe. ${ }^{51,54}$ Although some authors claim that sialoliths smaller than 2 to $3 \mathrm{~mm}$ may be overlooked because of the absence of acoustic shadow, these articles are from the 1980s and currently used machines have better resolution and detection possibilities. ${ }^{56,57}$ Sialolithiasis causes partial or total mechanical obstruction 


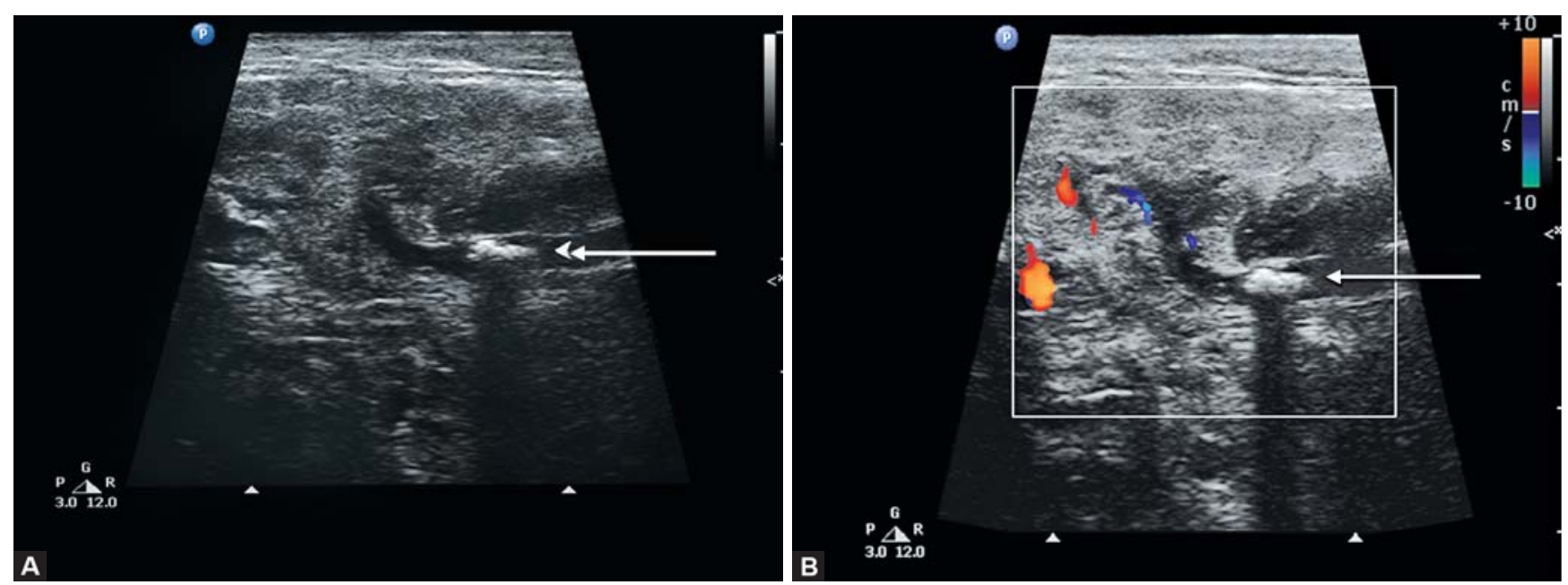

Figs 7A and B: B-mode US image (A) shows an enlarged submandibular gland with dilated Wharton duct and calculus within it (arrows), (B) color Doppler shows increased vascularity in the gland suggestive of coexisting inflammation (sialadenitis)

of the salivary duct, which results in recurrent swelling of a salivary gland during eating and may be complicated by bacterial infection. ${ }^{20,48}$

Sialoliths in the distal part of the submandibular duct (Wharton duct) may be palpable in the floor of the mouth. However, sialoliths in the proximal portion of the duct or in the parenchyma of salivary glands may be demonstrated only radiologically.

US features of sialolithiasis include hyperechoic foci with distal posterior acoustic shadowing, which represent stone. ${ }^{22}$ In symptomatic cases with duct occlusion, dilated excretory ducts are visible (Figs 7A and B). ${ }^{22}$

When sialolithiasis of the submandibular gland is suspected, US may demonstrate whether the stone is located in the glandular parenchyma or in the Wharton duct. ${ }^{58}$ This distinction is essential for choosing the method of treatment.

In chronic ductal sialolithiasis complicated by chronic or recurrent inflammation, the gland may lose its function. At this stage of disease, stones located in a nondilated duct may be difficult to demonstrate. In about $50 \%$ of patients, sialolithiasis coexists with inflammation. ${ }^{23}$ Hyperechoic bubbles of air mixed with saliva may mimic stones in the Wharton duct and thus be a diagnostic pitfall. ${ }^{19}$

\section{SIALOSIS}

Sialosis is a noninflammatory, non-neoplastic, recurrent, painless salivary gland swelling, usually bilateral, which most often concerns the parotid glands. Sialosis has been described in connection with endocrine diseases, malnutrition, hepatic cirrhosis, chronic alcoholism or different deficiency diseases (e.g. avitaminoses) ${ }^{20}$

US reveals enlarged, hyperechoic salivary glands with a poorly visible deep lobe but without focal lesions. ${ }^{9}$

\section{Sjogren's Syndrome}

Sjogren's syndrome is a chronic autoimmune disease predominantly affecting women over 40 years of age. It is characterized by intense lymphocytic and plasma cell infiltration and destruction of salivary and lacrimal glands..$^{59}$ Major clinical symptoms include a dry mouth and eyes. Advanced stages of Sjogren's syndrome may be recognizable at US examination of the parotid and submandibular glands. ${ }^{60}$ The disease may affect all salivary glands.

US features of advanced Sjogren's syndrome include inhomogeneous echotexture of the gland with scattered multiple small, oval, hypoechoic or anechoic areas, usually well-defined, and showing increased parenchymal blood flow on color Doppler studies (Fig. 8). ${ }^{9,32,61}$

Hypoechoic or anechoic areas are believed to represent infiltration by lymphatic cells, destroyed salivary parenchyma and dilated ducts.

Sjogren's syndrome is frequently associated with both reactive and neoplastic lymphoproliferative disease. ${ }^{62}$ Further US monitoring for early detection of possible lymphomatous change is required in patients with Sjogren's syndrome. ${ }^{63,64}$ Biopsy is recommended for lesions exceeding $2 \mathrm{~cm}$ or fast-growing lesions. ${ }^{9}$

Non-Hodgkin lymphoma manifesting as small multiple nodular disseminations with hypervascularization in the salivary gland has been reported. ${ }^{34,65}$ In addition, bilateral inflammation (acalculous), granulomatous disease (e.g. sarcoidosis), hematogenous metastases, and benign lymphoepithelial lesions in HIV-positive patients should be taken into consideration in cases of multiple hypoechoic areas scattered in salivary gland parenchyma. $23,25,33,35,42,43$ 


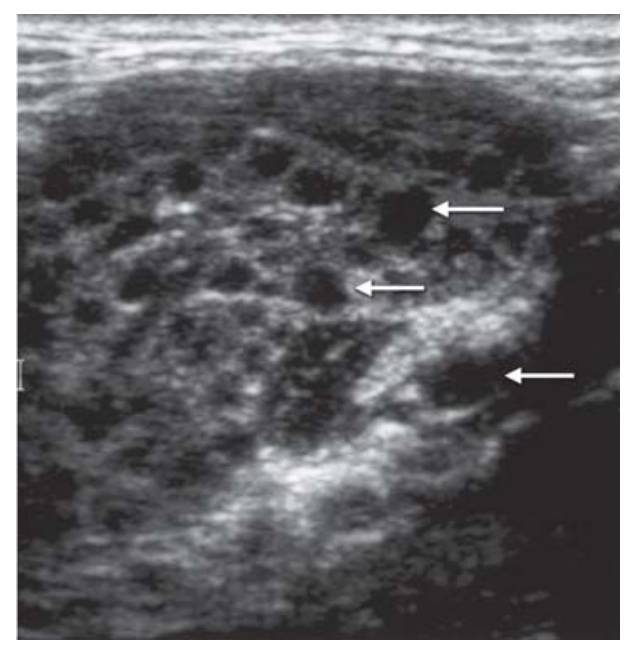

Fig. 8: B-mode US image shows Sjogren's syndrome in the parotid gland. The gland has an inhomogeneous structure with multiple small, oval, hypoechoic areas (arrows)

\section{NEOPLASMS}

Salivary gland neoplasms are relatively rare. Most of them are benign (70-80\%) and found in the parotid glands (80$90 \%$ ). About 10 to $12 \%$ of all salivary gland neoplasms are located in the submandibular glands, but almost half of these neoplasms may be malignant. ${ }^{3,66}$

\section{Benign Neoplasms}

The most common benign neoplasms of major salivary glands are pleomorphic adenomas (mixed tumor) and Warthin tumors (adenolymphoma, cyst adenolymphoma, papillary cystadenoma lymphomatosum). Clinically, they manifest as slow growing painless masses. ${ }^{67}$

\section{Pleomorphic Adenoma}

Pleomorphic adenomas occur most often in the parotid gland (60-90\%) in people in the fourth and fifth decades of life but may arise at any age. ${ }^{3,66,68}$ There is a slight predominance in women. ${ }^{66}$

Pleomorphic adenomas are usually solitary and unilateral. ${ }^{3,66,68}$ They grow slowly and maybe asymptomatic. Nontreated pleomorphic adenomas may undergo malignant transformation after decades. ${ }^{3,68}$ In exceptional cases, pleomorphic adenomas may be clinically aggressive; they may metastasize and even be fatal. ${ }^{20,69,70}$

At US, pleomorphic adenomas are hypoechoic, welldefined, lobulated tumors with posterior acoustic enhancement and may contain calcifications. ${ }^{71-73}$ The feature of lobulated shape is being emphasized in differential diagnosis (Figs 9A and B). ${ }^{73}$

Vascularization in pleomorphic adenomas is often poor or absent (even when the sensitive power Doppler mode is used) but may be abundant (Figs 9A and B). ${ }^{71,73,74}$ After inadequate surgery, pleomorphic adenomas often recur, usually multifocally. ${ }^{75}$

\section{Warthin Tumor}

Warthin tumor is the next most common benign salivary neoplasm (5-10\% of all benign salivary neoplasms). ${ }^{66,68} \mathrm{It}$ arises most often in men in the fifth and sixth decades of life. ${ }^{66,68,76}$ The relationship between smoking and development of Warthin tumors has been proved. ${ }^{67}$

Warthin tumor is usually solitary, unilateral, and slow growing. In about 10 to $60 \%$ of cases, tumors may occur bilaterally or multifocally, sometimes metachronously, growing and manifesting clinically at different times. $3,68,77,78$ Sporadically, the epithelial component of Warthin tumor may undergo malignant transformation. ${ }^{68,79}$

At US, Warthin tumors are oval, hypoechoic, welldefined tumors and often contain multiple anechoic areas. ${ }^{25,74,78,80}$ Warthin tumors are often hypervascularized (Fig. 10).

Diagnosis of a Warthin tumor may be supported by results of technetium-99m scintigraphy, which reveals a 'hot' tumor because of the increased uptake of the tracer by the tumor. ${ }^{81}$

Lobulated shape in pleomorphic adenomas and anechoic areas in Warthin tumors, although common, are not pathognomonic and may be found in many other lesions, including malignancies. ${ }^{73,74}$

\section{Other Benign Tumors}

Other benign tumors (e.g. oncocytoma, basal cell adenoma) occur less frequently in the salivary glands. Their differentiation is not possible with US. Among nonepithelial lesions, hemangiomas, lipomas and neurinomas or schwannomas (Fig. 11) may be found in salivary glands. ${ }^{12,87-91}$

Hemangiomas, the most frequent tumors in infants, may manifest as heterogeneous lesions with sinusoidal spaces and calcifications representing phleboliths (Figs 12A and B). ${ }^{88}$

Hemangioendothelioma (HAE) of the parotid gland is a benign tumor that presents in infancy as a large, rapidly growing mass that is either small or not noticed at birth, but becomes apparent soon after ${ }^{88}$ (Fig. 13).

Lipomas are usually oval and hypoechoic with sharp margins and hyperechoic linear structures regularly distributed within the lesion in a striated or feathered pattern., ${ }^{9,92}$

\section{MALIGNANT NEOPLASMS}

The most common malignant neoplasms occurring in salivary glands are mucoepidermoid carcinoma and adenoid cystic carcinoma. ${ }^{94}$ Squamous cell carcinoma, acinic cell carcinoma, and adenocarcinoma are less common. 


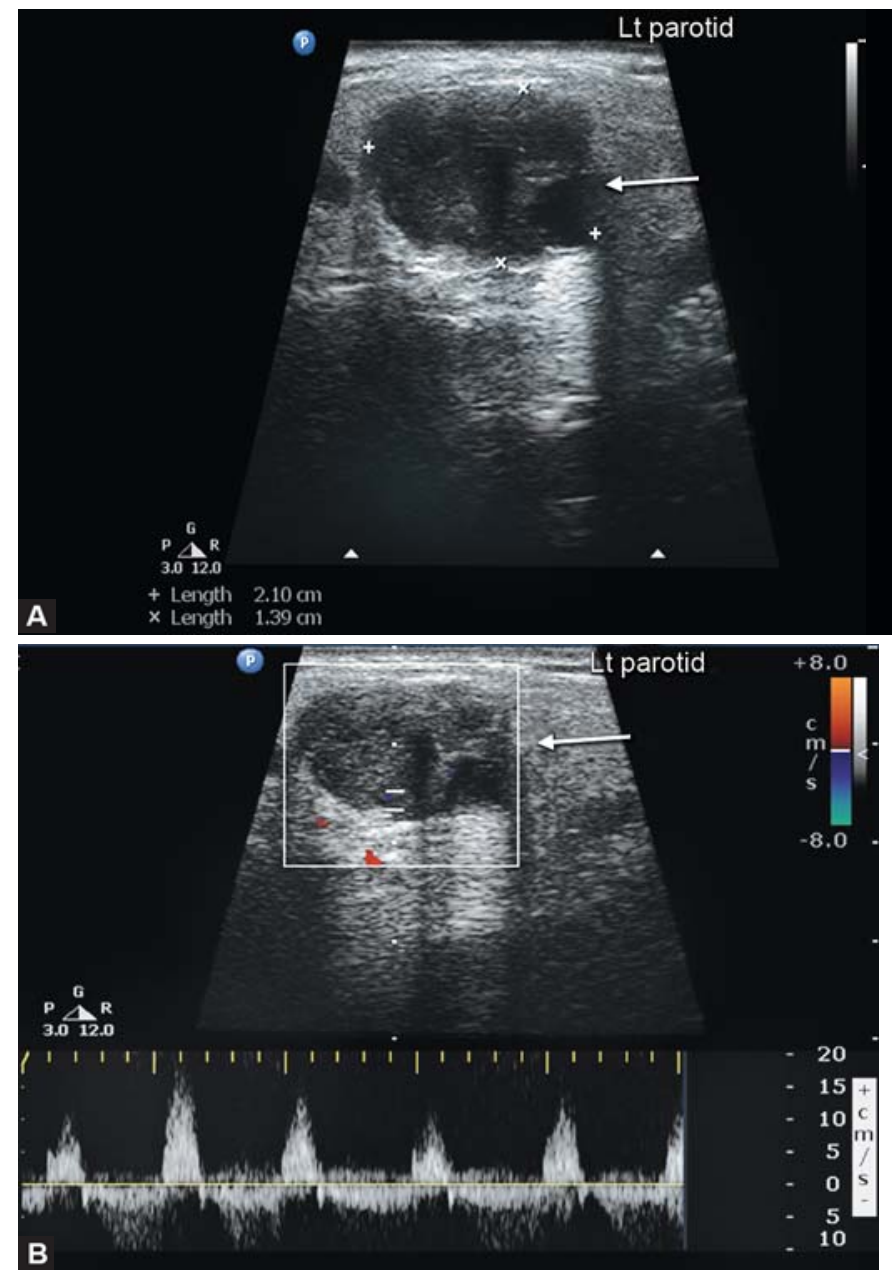

Figs 9A and B: Gray-scale US image (A) shows the typical appearance of a pleomorphic adenoma (arrows). The lesion is hypoechoic and lobulated with distinct borders and posterior acoustic enhancement. Color Doppler US image (B) shows a pleomorphic adenoma (arrows) in the lower pole of the parotid gland. Vascularity seen within the lesion
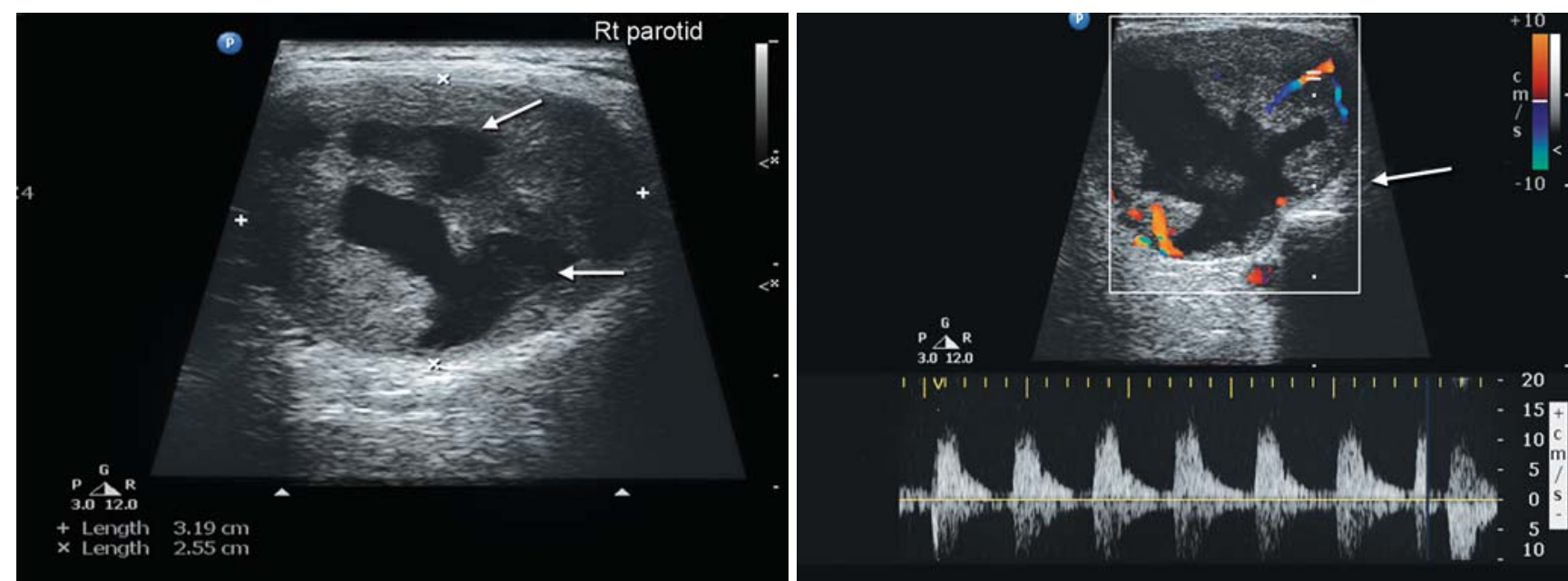

Fig. 10: Gray-scale US image shows the typical appearance of a Warthin tumor. The lesion, which is located in the lower pole of the parotid gland, is oval, well-defined, hypoechoic, and inhomogeneous with multiple irregular anechoic areas (arrows) and posterior acoustic enhancement. Color Doppler US image shows a hypervascularized Warthin tumor (arrows) in the parotid gland

Less than $30 \%$ of focal lesions in the parotid gland are malignant, whereas almost $50 \%$ of focal lesions in the submandibular gland are malignant. ${ }^{3,66}$ Unlike benign salivary neoplasms, malignant tumors may grow rapidly, may be tender or painful at palpation, and may cause facial nerve paresis or paralysis. ${ }^{3,20,94}$
Mucoepidermoid carcinoma occurs mostly between 30 and 50 years of age. The macroscopic appearance of the tumor, and similarly its imaging features, depend mostly on the level of malignancy. 8,20

Well-differentiated tumors may be similar to benign tumors at US. ${ }^{8}$ Adenoid cystic carcinoma, which is a slowly 


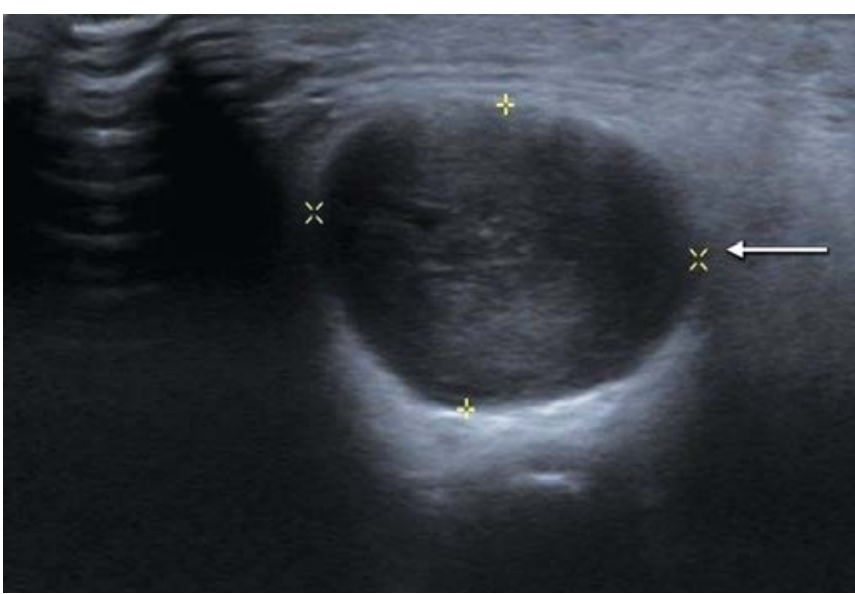

Fig. 11: Sonography of the right parotid gland showed a $14 \times 22 \mathrm{~mm}$ hypoechoic, well-defined mass within the parotid gland. It showed a homogenous and well-encapsulated appearance. These ultrasound images favor a diagnosis of a benign tumor of the parotid salivary gland. Biopsy of the mass showed it to be parotid gland schwannoma (the tumor having arisen from the facial nerve within the parotid) growing tumor, shows a particular tendency to nerve infiltration (and thus pain), and late metastases are frequent. ${ }^{20}$

Classic US features of poorly differentiated or advanced malignant neoplasms of salivary glands are like those in other organs or tissues.

US features of malignant salivary neoplasms include the following: an irregular shape, irregular borders, blurred margins, and a hypoechoic inhomogeneous parenchyma. 8,19,25,41,95,96 However, malignant tumors may also be homogeneous and well-defined. ${ }^{18,73,96}$ The internal structure of a malignant tumor at US may be not only solid but also cystic or cystic with a mural solid nodule. ${ }^{85}$ Malignant tumors may have a lobulated shape, similar to that of pleomorphic adenomas. ${ }^{96}$

Vascularization of malignant tumors is not pathognomonic, and assessment with color Doppler or power Doppler US does not allow reliable differentiation between benign and malignant salivary gland tumors. ${ }^{72,76}$ However,
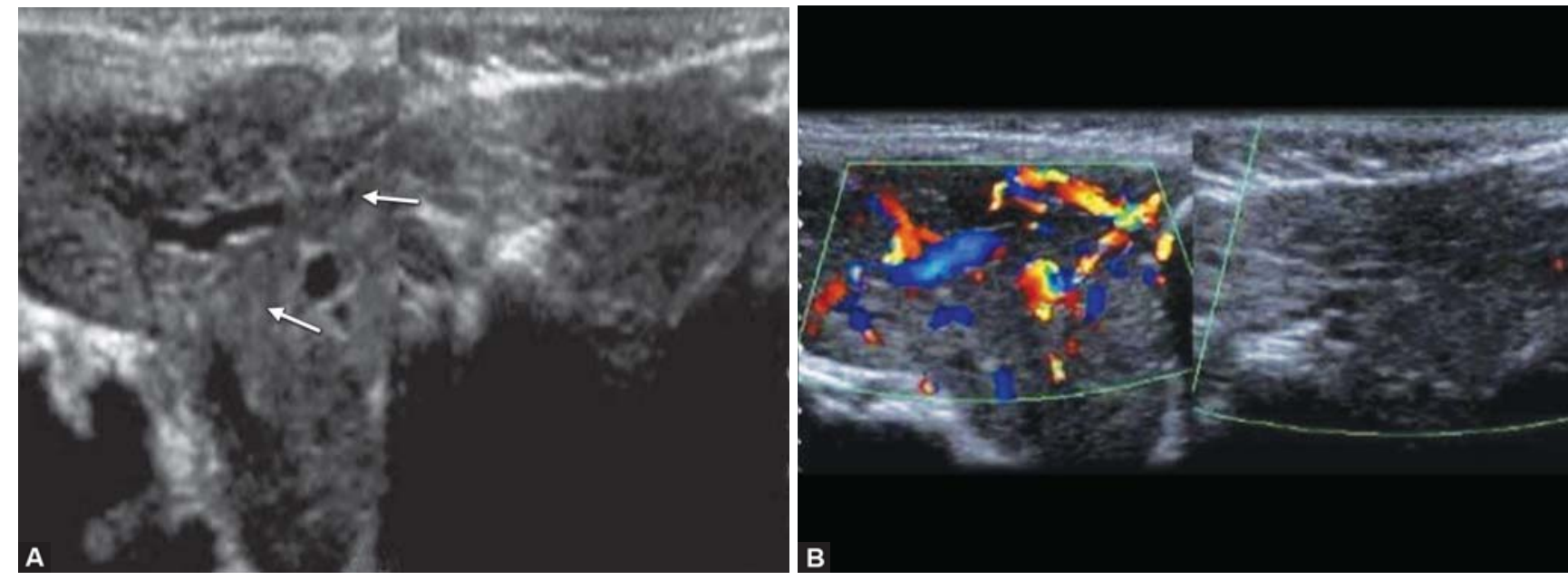

Figs 12A and B: (A) Gray scale ultrasound image demonstrates heterogeneous predominantly hypoechoic enlarged right parotid gland (arrows) compared to the left parotid gland, (B) color Doppler image shows hypervascularity of the right parotid gland favors a parotid hemangioma
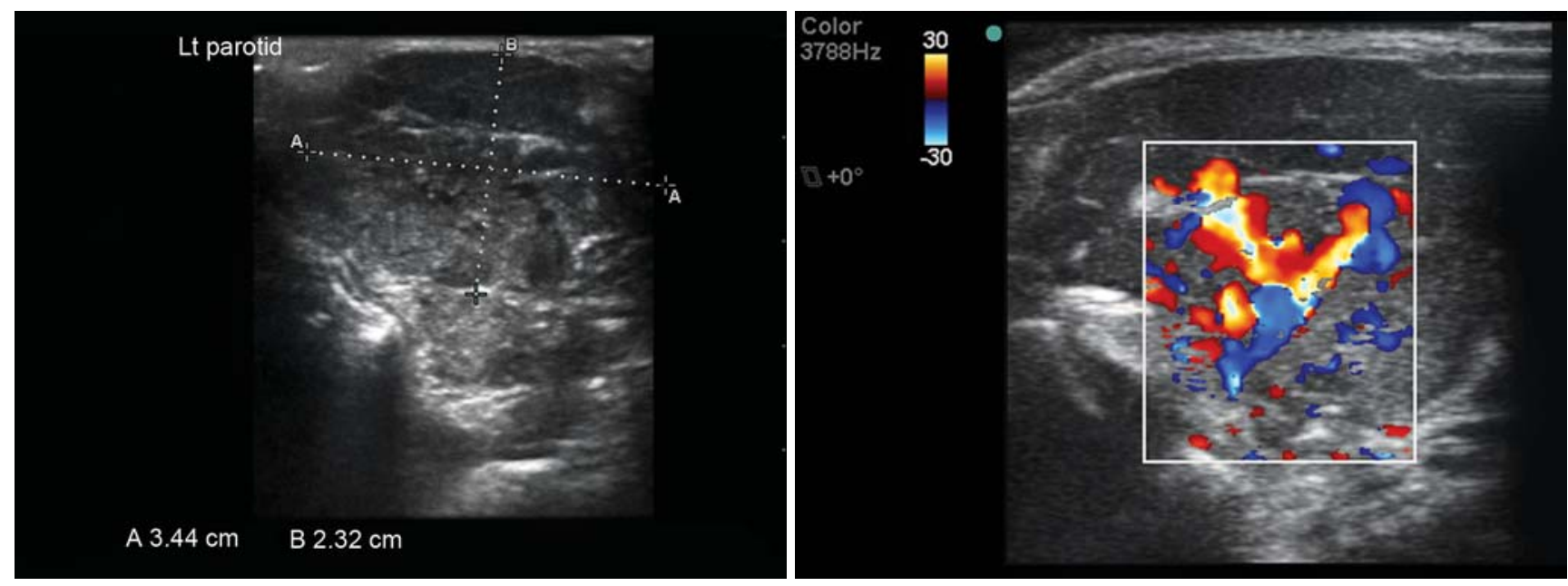

Fig. 13: Ultrasound showed a homogeneous mass enlarging and replacing most or all of the visualized parotid gland, with a lobular internal structure, fine echogenic internal septations. Color Doppler imaging showed extremely high vascularity within the mass favors hemangioendothelioma of parotid glands 

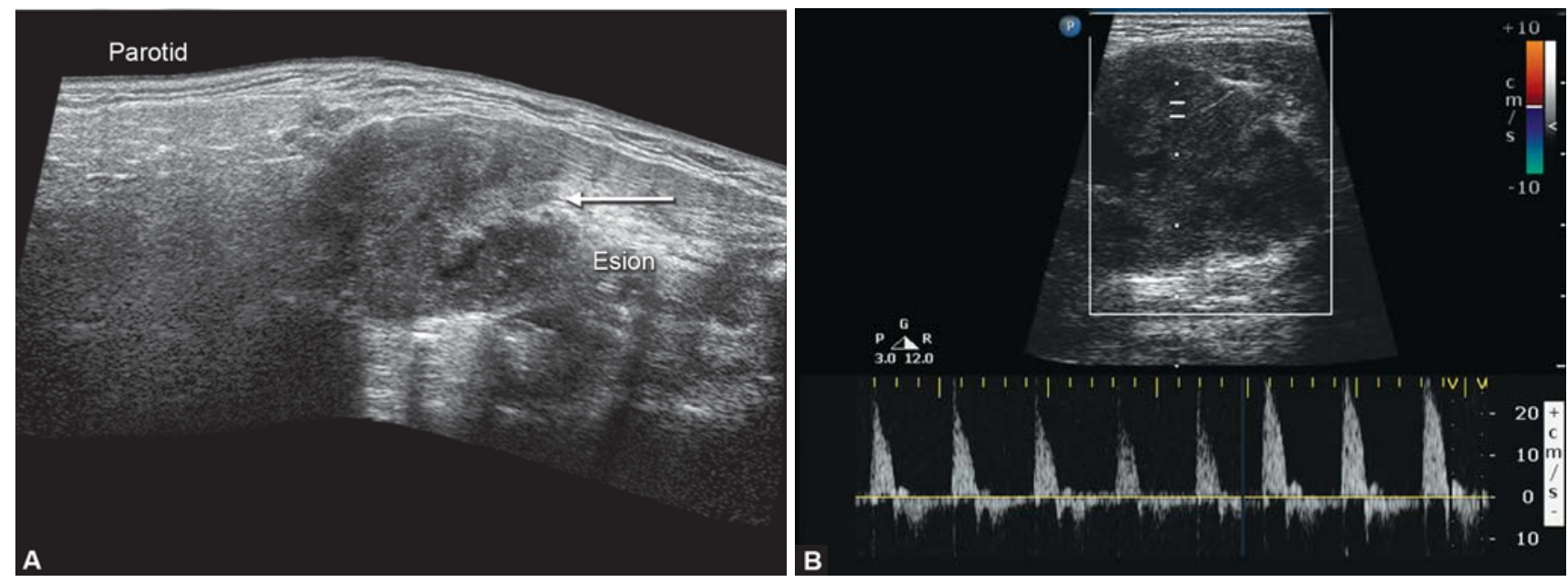

Figs 14A and B: Panoramic gray-scale US image shows an acinic cell carcinoma (arrow) in the left parotid gland. The tumor is well-defined and has regular margins (A) color Doppler reveals increased vascularity within the mass lesion with high peak systolic flow noted (B)

Schick et $\mathrm{al}^{72}$ report that high vascularization and high systolic peak flow velocity should raise the suspicion of malignancy (Figs 14A and B). Bradley et $\mathrm{al}^{97}$ concluded that tumors demonstrating an increased intratumoral vascular resistance index have an increased risk of malignancy.

The presence of metastatic-appearing lymph nodes accompanying a tumor in the salivary gland strongly suggests a malignancy.

\section{METASTASES}

Salivary glands are very uncommon sites of metastases. Primary tumors metastasizing to salivary glands may be located in the head and neck region, as well as in more distant parts of the body. Melanoma spinocellular cancer, breast cancer, and lung cancer may produce metastases to intraparotid lymph nodes. ${ }^{99-103}$ Extremely rare are metastases from renal cancer. ${ }^{100,104-106}$

At US, metastases may be well-defined and oval. ${ }^{9}$ It may be difficult to differentiate multiple metastatic lesions from some patterns of inflammation, Sjogren's syndrome and granulomatous disease at US. ${ }^{23,25,33,42,43}$

\section{LYMPHOMA}

Salivary glands may also be affected by lymphoma. ${ }^{34}$ However, primary involvement of salivary glands is rare; they are usually one of the sites of systemic disease.

Clinically, salivary lymphomas most often manifest as a painless, progressive swelling. ${ }^{107,108}$ They are usually associated with autoimmune disease, most often with Sjogren's syndrome, sometimes also with rheumatoid arthritis. $^{62-64,109}$

At US of cases of lymphoma in the salivary gland, one may observe a solitary, hypoechoic, homogeneous or inhomogeneous lesion, which is oval or lobulated or has irregular margins and sometimes contains echogenic septa or stripes (Fig. 15). ${ }^{34,110,111}$ However, these features are not pathognomonic, and lymphoma may not be reliably differentiated from other neoplastic or non-neoplastic salivary gland tumors with US.

A pattern of multiple hypoechoic lesions with increased blood flow may also be seen. ${ }^{34,111}$ Such a pattern requires differentiation from inflammation, Sjogren's syndrome, granulomatous disease (e.g. sarcoidosis), and hematogenous metastases. $^{23,25,32,33,42,43}$

In cases of lymphoma, solitary or multiple salivary gland lesions sometimes associated with microcysts may be observed at CT or MR imaging. ${ }^{63,109}$

\section{CYSTS}

Simple cysts are uncommon in salivary glands. They may be congenital or acquired. Some acquired cysts develop due to obstruction of the salivary ducts in the presence of a tumor, stones, or inflammation. ${ }^{3}$ Clinically, they usually manifest as a painless swelling but may be tender when infected. ${ }^{41}$

US features of a cyst are well-defined margins, anechoic content, posterior acoustic enhancement and avascular at power Doppler or color Doppler imaging (Fig. 16). ${ }^{22}$

Benign lymphoepithelial lesions in HIV-positive patients may manifest as multiple cysts. ${ }^{35}$

\section{EFFECTS OF IRRADIATION}

The major salivary glands are often irradiated during radiation therapy of head and neck neoplasms. A major adverse effect of such treatment is xerostomia caused by functional and structural impairment of salivary parenchyma. ${ }^{11,115}$ Loss of salivary gland function significantly diminishes the patient's quality of life. ${ }^{116}$ 


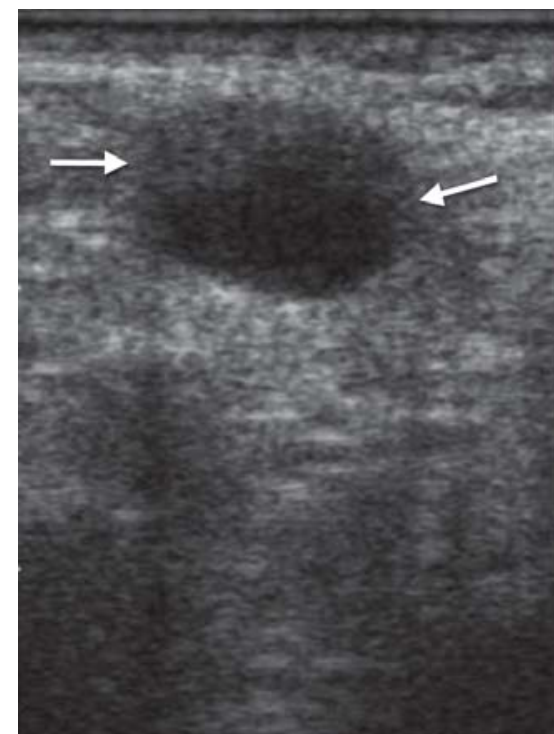

Fig. 15: Gray-scale US image of a patient with non-Hodgkin lymphoma shows a lymphomatous lymph node (arrows) in the parotid gland. The oval, well-defined, anechoic lesion demonstrates discrete posterior enhancement

The most useful method for evaluation of salivary excretory function remains scintigraphy, especially single photon emission CT (SPECT). ${ }^{10,11}$ Carbon 11-methionine positron emission tomography (PET) offers new possibilities for studying the individual response of major salivary glands to irradiation. ${ }^{117}$ After irradiation, salivary glands become hypoechoic and inhomogeneous at US. The salivary glands enlarge in the acute phase and later become smaller because of atrophy. ${ }^{19,118,119}$

\section{TRAUMA}

Traumatic injuries of the salivary glands occur most often in the parotid gland because the other major salivary glands are protected by the mandible. After salivary gland trauma, US may demonstrate a hematoma, other fluid collections (e.g. a sialocele), or a fistula in the parotid gland or surrounding structures. ${ }^{13,19,120,121}$ Suspected damage to the facial nerve or Stensen's duct warrants application of other imaging modalities (CT, MR, sialography). ${ }^{19}$

\section{CONCLUSION}

US is a valuable and useful method for diagnosis of salivary gland diseases. Not only does it enable confirmation or exclusion of the presence of a mass, but in many cases the nature of underlying disease may also be suggested on the basis of US findings. Use of high resolution high frequency linear ultrasound imaging helps us to evaluate the morphological patterns of salivary gland diseases in dayto-day clinical scenarios. USG-guided FNAC is a great adjunct tool in achieving final tissue diagnosis in evaluation of salivary gland masses.

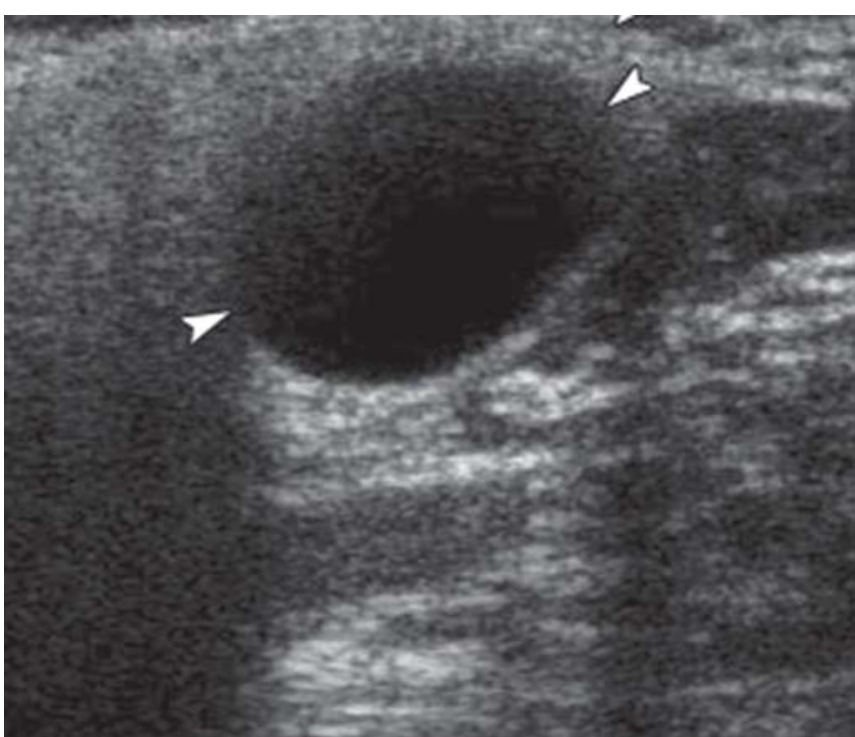

Fig. 16: Gray-scale US image shows a simple cyst (arrowheads) in the lower pole of the parotid gland

\section{REFERENCES}

1. Rabinov JD. Imaging of salivary gland pathology. Radiol Clin North Am 2000 Sep;38(5):1047-1057.

2. Yousem DM, Kraut MA, Chalian AA. Major salivary gland imaging. Radiology 2000 Jul;216(1):19-29.

3. Silvers AR, Som PM. Salivary glands. Radiol Clin North Am 1998 Sep;36(5):941-966.

4. Alyas F, Lewis K, Williams M, Moody AB, Wong KT, Ahuja AT, Howlett DC. Diseases of the submandibular gland as demonstrated using high resolution ultrasound. Br J Radiol 2005 Apr;78(928):362-369.

5. Ridder GJ, Richter B, Disko U, Sander A. Gray-scale sonographic evaluation of cervical lymphadenopathy in catscratch disease. J Clin Ultrasound 2001 Mar-Apr;29(3):140-145.

6. Ying M, Ahuja A, Metreweli C. Diagnostic accuracy of sonographic criteria for evaluation of cervical lymphadenopathy. J Ultrasound Med 1998 Jul;17(7):437-445.

7. Ying M, Ahuja A. Sonography of neck lymph nodes. Part I: normal lymph nodes. Clin Radiol 2003 May;58(5):351-358.

8. Howlett DC, Kesse KW, Hughes DV, Sallomi DF. The role of imaging in the evaluation of parotid disease. Clin Radiol 2002 Aug;57(8):692-701.

9. Gritzmann N, Rettenbacher T, Hollerweger A, Macheiner P, Hubner E. Sonography of the salivary glands. Eur Radiol 2003 May;13(5):964-975.

10. Bussels B, Maes A, Flamen P, Lambin P, Erven K, Hermans R, Nuyts S, Weltens C, Cecere S, Lesaffre E, et al. Dose-response relationships within the parotid gland after radiotherapy for head and neck cancer. Radiother Oncol 2004 Dec;73(3):297-306.

11. Roesink JM, Moerland MA, Hoekstra A, Van Rijk PP, Terhaard $\mathrm{CH}$. Scintigraphic assessment of early and late parotid gland function after radiotherapy for head-and-neck cancer: a prospective study of dose-volume response relationships. Int J Radiat Oncol Biol Phys 2004 Apr;58(5):1451-1460.

12. Koischwitz D, Gritzmann N. Ultrasound of the neck. Radiol Clin North Am 2000 Sep;38(5):1029-1045. 
13. Candiani F, Martinoli C. Salivary glands. In: Solbiati L, Rizzatto G, editors. Ultrasound of superficial structures. Edinburgh, Scotland: Churchill Livingstone; 1995. p 125-139.

14. Laing MR, McKerrow WS. Intraparotid anatomy of the facial nerve and retromandibular vein. Br J Surg 1988 Apr;75(4): 310-312.

15. Takahashi N, Okamoto K, Ohkubo M, Kawana M. Highresolution magnetic resonance of the extracranial facial nerve and parotid duct: demonstration of the branches of the intraparotid facial nerve and its relation to parotid tumours by MRI with a surface coil. Clin Radiol 2005 Mar;60(3):349-354.

16. Divi V, Fatt MA, Teknos TN, Mukherji SK. Use of crosssectional imaging in predicting surgical location of parotid neoplasms. J Comput Assist Tomogr 2005 May-Jun;29(3): 315-319.

17. Lin DT, Coppit GL, Burkey BB, Netterville JL. Tumors of the accessory lobe of the parotid gland: a 10-year experience. Laryngoscope 2004 Sep;114(9):1652-1655.

18. Yoshihara T, Suzuki S, Nagao K. Mucoepidermoid carcinoma arising in the accessory parotid gland. Int J Pediatr Otorhinolaryngol 1999 Apr;48(1):47-52.

19. Bradley MJ. Salivary glands. In: Ahuja AT, Evans RM, editors. Practical head and neck ultrasound. London, England: Greenwich Medical Media; 2000. p 19-33.

20. Sikorowa L, Meyza JW, Ackerman LW. Salivary gland tumors. New York, NY: Pergamon Press; 1982;46.

21. Brook I. Acute bacterial suppurative parotitis: microbiology and management. J Craniofac Surg 2003 Jan;14(1):37-40.

22. Traxler M, Schurawitzki H, Ulm C, Solar P, Blahout R, Piehslinger E, Schadlbauer E. Sonography of non-neoplastic disorders of the salivary glands. Int J Oral Maxillofac Surg 1992 Dec;21(6):360-363.

23. Ching AS, Ahuja AT, King AD, Tse GM, Metreveli C. Comparison of the sonographic features of acalculous and calculous submandibular sialadenitis. J Clin Ultrasound 2001 Jul-Aug;29(6):332-338.

24. Garcia CJ, Flores PA, Arce JD, Chuaqui B, Schwartz DS. Ultrasonography in the study of salivary gland lesions in children. Pediatr Radiol 1998 Jun;28(6):418-425.

25. Shimizu M, Ussmuller J, Donath K, Yoshiura K, Ban S, Kanda S, Ozeki S, Shinohara M. Sonographic analysis of recurrent parotitis in children: a comparative study with sialographic findings. Oral Surg Oral Med Oral Pathol Oral Radiol Endod 1998 Nov;86(5):606-615.

26. Tschammler A, Ott G, Schang T, Seelbach-Goebel B, Schwager K, Hahn D. Lymphadenopathy: differentiation of benign from malignant disease - color Doppler US assessment of intranodal angioarchitecture. Radiology 1998 Jul;208(1):117-123.

27. Duff TB. Parotitis, parotid abscess and facial palsy. J Laryngol Otol 1972 Feb;86(2):161-165.

28. Nozaki H, Harasawa A, Hara H, Kohno A, Shigeta A. Ultrasonographic features of recurrent parotitis in childhood. Pediatr Radiol 1994;24(2):98-100.

29. Yeow KM, Hao SP, Liao CT. US-guided percutaneous catheter drainage of parotid abscesses. J Vasc Interv Radiol 2000 Apr;11(4):473-476.

30. Bhatty MA, Piggot TA, Soames JV, McLean NR. Chronic nonspecific parotid sialadenitis. Br J Plast Surg 1998 Oct;51(7): 517-521.
31. Nozaki H, Harasawa A, Hara H, Kohno A, Shigeta A. Ultrasonographic features of recurrent parotitis in childhood. Pediatr Radiol 1994;24:98-100.

32. Bradus RJ, Hybarjer P, Gooding GA. Parotid gland: US findings in Sjogren's syndrome. Work in progress. Radiology 1988 Dec;169(3):749-751.

33. Gnepp DR. Metastatic disease to the major salivary glands. In: Ellis GL, Auclair PL, Gnepp DR, editors. Surgical pathology of the salivary glands. Philadelphia, PA: Saunders; 1991.560 p.

34. Chiou HJ, Chou YH, Chiou SY, Chen WM, Chen W, Wang HK, Chang CY. High-resolution ultrasonography of primary peripheral soft tissue lymphoma. J Ultrasound Med 2005 Jan;24(1):77-86.

35. Martinoli C, Pretolesi F, Del Bono V, Derchi LE, Mecca D, Chiaramondia M. Benign lymphoepithelial parotid lesions in HIV-positive patients: spectrum of findings at gray-scale and Doppler sonography. AJR Am J Roentgenol 1995 Oct;165(4):975-979.

36. Ahuja AT, Richards PS, Wong KT, King AD, Yuen HY, Ching AS, To EW, To KF. Kuttner's tumour (chronic sclerosing sialadenitis) of the submandibular gland: sonographic appearances. Ultrasound Med Biol 2003 Jul;29(7):913-919.

37. Bialek EJ, Osmolski A, Karpinska G, Fedorowicz M, Jakubowski W, Zajkowski P, Serafin-Krol M. US appearance of a Kuttner's tumor resembling a malignant lesion: UShistopathologic correlation. Eur J Ultrasound 2001 Dec; 14(2):167-170.

38. Siewert B, Kruskal JB, Kelly D, Sosna J, Kane RA. Utility and safety of ultrasound-guided fine needle aspiration of salivary gland masses including a cytologist's review. J Ultrasound Med 2004 Jun;23(6):777-783.

39. Wan YL, Chan SC, Chen YL, Cheung YC, Lui KW, Wong HF, Hsueh C, See LC. Ultrasonography-guided core-needle biopsy of parotid gland masses. AJNR Am J Neuroradiol 2004 Oct;25(9):1608-1612.

40. Fischer T, Filimonow S, Petersein J, Zimmer C, Beyersdorff D, Guski H. Diagnosis of Heerfordt's syndrome by state-of-theart ultrasound in combination with parotid biopsy: a case report. Eur Radiol 2002;12(1):134-137.

41. Howlett DC. High resolution ultrasound assessment of the parotid gland. Br J Radiol 2003 Apr;76(904):271-277.

42. Iko BO, Chinwuba CE, Myers EM, Teal JS. Sarcoidosis of the parotid gland. Br J Radiol 1986 Jun;59(702):547-552.

43. Martinoli C, Derchi LE, Solbiati L, Rizzatto G, Silvestri E, Giannoni M. Color Doppler sonography of salivary glands. AJR Am J Roentgenol 1994 Oct;163(4):933-941.

44. Holmes S, Gleeson MJ, Cawson RA. Mycobacterial disease of the parotid gland. Oral Surg Oral Med Oral Pathol Oral Radiol Endod 2000 Sep;90(3):292-298.

45. Chou YH, Tiu CM, Liu CY, Hong TM, Lin CZ, Chiou HJ, Chiou SY, Chang CY, Chen MS. Tuberculosis of the parotid gland: sonographic manifestations and sonographically guided aspiration. J Ultrasound Med 2004 Oct;23(10):1275-1281.

46. Sa'do B, Yoshiura K, Yuasa K, Ariji Y, Kanda S, Oka M, Katsuki T. Multimodality imaging of cervicofacial actinomycosis. Oral Surg Oral Med Oral Pathol 1993 Dec;76(6):772-782.

47. Escudier MP, McGurk M. Symptomatic sialadenitis and sialolithiasis in the English population: an estimate of the cost of hospital treatment. Br Dent J 1999 May;186(9):463-466. 
48. Lustmann J, Regev E, Melamed Y. Sialolithiasis: a survey on 245 patients and a review of the literature. Int J Oral Maxillofac Surg 1990 Jun;19(3):135-138.

49. Marchal F, Dulgerov P, Becker M, Barki G, Disant F, Lehmann W. Specificity of parotid sialendoscopy. Laryngoscope 2001 Feb;111(2):264-271.

50. Marchal F, Dulgerov P, Becker M, Barki G, Disant F, Lehmann W. Submandibular diagnostic and interventional sialendoscopy: new procedure for ductal disorders. Ann Otol Rhinol Laryngol 2002 Jan;111(1):27-35.

51. Yoshimura Y, Inone Y, Odagana T. Sonographic evaluation of sialolithiasis. J Oral Maxillofac Surg 1989;47:907-912.

52. Rauch S, Gorlin RJ. Disease of the salivary glands. In: Gorlin RJ, Goldmann HM, editors. Thomas' oral pathology. St Louis, Mo: Mosby; 1970. p 997-1003.

53. Avrahami E, Englender M, Chen E, Shabaty D, Katz R, Harell M. CT of submandibular gland sialolithiasis. Neuroradiology 1996 Apr;38(3):287-290.

54. Jager L, Menauer F, Holzknecht N, Scholz V, Grevers G, Reiser M. Sialolithiasis: MR sialography of the submandibular ductan alternative to conventional sialography and US? Radiology 2000 Sep;216(3):665-671.

55. Becker M, Marchal F, Becker CD, Dulguerov P, Georgakopoulos G, Lehmann W, Terrier F. Sialolithiasis and salivary ductal stenosis: diagnostic accuracy of MR sialography with a three-dimensional extended-phase conjugate-symmetry rapid spinecho sequence. Radiology 2000 Nov;217(2):347-358.

56. Gritzmann N. Sonography of the salivary glands. AJR Am J Roentgenol 1989 Jul;53(1):161-166.

57. Rinast E, Gmelin E, Hollands-Thorn B. Digital subtraction sialography, conventional sialography, high-resolution ultrasonography and computed tomography in the diagnosis of salivary gland diseases. Eur J Radiol 1989 Nov;9(4):224-230.

58. Iro H, Schneider T, Nitsche N, Waitz G, Marienhagen J, Ell C. Extracorporeal shock wave lithotripsy of a salivary stone. Dtsch Med Wochenschr 1990 Jan;115(1):12-14.

59. Kumar V, Cotran RS, Robbins SL. Disorders of the immune system. In: Kumar V, editor. Basic pathology. 6th ed. Philadelphia, PA: Saunders; 1997. p 111-112.

60. Makula E, Pokorny G, Kiss M, Vörös E, Kovács L, Kovács A, Csernay L, Palkó A. The place of magnetic resonance and ultrasonographic examinations of the parotid gland in the diagnosis and follow-up of primary Sjogren's syndrome. Rheumatology (Oxford) 2000 Jan;39(1):97-104.

61. Niemela RK, Takalo R, Paakko E, Suramo I, Päivänsalo M, Salo T, Hakala M. Ultrasonography of salivary glands in primary Sjogren's syndrome: a comparison with magnetic resonance imaging and magnetic resonance sialography of parotid glands. Rheumatology (Oxford) 2004 Jul;43(7):875-879.

62. McCurley TL, Collins RD, Ball E, Collins RD. Nodal and extranodal lymphoproliferative disorders in Sjogren's syndrome: a clinical and immunopathologic study. Hum Pathol 1990 May;21(5):482-492.

63. Tonami H, Matoba M, Kuginuki Y, Yokota H, Higashi K, Yamamoto I, Sugai S. Clinical and imaging findings of lymphoma in patients with Sjogren's syndrome. J Comput Assist Tomogr 2003 Jul-Aug;27(4):517-524.

64. Masaki Y, Sugai S. Lymphoproliferative disorders in Sjogren's syndrome. Autoimmun Rev 2004 Mar;3(3):175-182.
65. Matsushita T, Takashima S, Takayama F, Momose M, Wang J, Ishiyama T. Sonographic detection of secondary MALT lymphoma of the submandibular gland. J Clin Ultrasound 2001 Oct;29(8):462-465.

66. Renehan A, Gleave EN, Hancock BD, Smith P, McGurk M. Long-term follow-up of over 1000 patients with salivary gland tumours treated in a single centre. Br J Surg 1996 Dec; 83(12):1750-1754.

67. Yoo GH, Eisele DW, Askin FB, Driben JS, Johns ME. Warthin's tumor: a 40-year experience at the Johns Hopkins Hospital. Laryngoscope 1994 Jul;104(7):799-803.

68. Ellis GL, Auclair PL, Gnepp DR, editors. Surgical pathology of the salivary glands. Philadelphia, PA: Saunders 1991:10-25.7.

69. Joe VQ, Westesson PL. Tumors of the parotid gland: MR imaging characteristics of various histologic types. Am J Roentgenol 1994 Aug;163(2):433-438.

70. Klijanienko J, El-Naggar AK, Servois V, Rodriguez J, Validire P, Vielh P. Clinically aggressive metastasizing pleomorphic adenoma: report of two cases. Head Neck 1997 Oct;19(7): 629-633.

71. Bialek EJ, Jakubowski W, Karpinska G. Role of ultrasonography in diagnosis and differentiation of pleomorphic adenomas: work in progress. Arch Otolaryngol Head Neck Surg 2003 Sep;129(9):929-933.

72. Schick S, Steiner E, Gahleitner A, Böhm P, Helbich T, BaSsalamah A, Mostbeck G. Differentiation of benign and malignant tumors of the parotid gland: value of pulsed Doppler and color Doppler sonography. Eur Radiol 1998;8(8):1462-1467.

73. Shimizu M, Ussmuller J, Hartwein J, Donath K, Kinukawa N. Statistical study for sonographic differential diagnosis of tumorous lesions in the parotid gland. Oral Surg Oral Med Oral Pathol Oral Radiol Endod 1999 Aug;88(2):226-233.

74. Zajkowski P, Jakubowski W, Bia33ek EJ, Wysocki M, Osmólski A, Serafin-Król M. Pleomorphic adenoma and adenolymphoma in ultrasonography. Eur J Ultrasound 2000 Sep;12(1):23-29.

75. Laskawi R, Schott T, Schröder M. Recurrent pleomorphic adenomas of the parotid gland: clinical evaluation and longterm follow-up. Br J Oral Maxillofac Surg 1998 Feb;36(1): 48-51.

76. Dumitriu D, Dudea SM, Botar-Jid C, Băciuţ G. Ultrasonographic and sonoelastographic features of pleomorphic adenomas of the salivary glands. Med Ultrason 2010 Sep;12(3):175-183.

77. Zajkowski P, Jakubowski W, Bia?ek EJ, Wysocki M, Osmólski A, Serafin-Król M. Pleomorphic adenoma and adenolymphoma in ultrasonography.Eur J Ultrasound 2000 Sep;12(1):23-29.

78. Yu GY, Ma DQ, Zhang Y, Peng X, Cai ZG, Gao Y, Chen Y. Multiple primary tumours of the parotid gland. Int J Oral Maxillofac Surg 2004 Sep;33(6):531-534.

79. Podlesák T, Dolecková V, Sibl O. Malignancy of a cystadenolymphoma of the parotid gland. Eur Arch Otorhinolaryngol 1992;249(4):233-235.

80. Kim J, Kim EK, Park CS, Choi YS, Kim YH, Choi EC. Characteristic sonographic findings of Warthin's tumor in the parotid gland. J Clin Ultrasound 2004 Feb;32(2):78-81.

81. Canbay AE, Knorz S, Heimann KD, Hildmann H, Tiedjen KU. Sonography and scintigraphy in the diagnosis of cystadenolymphomas (warthin tumor). Laryngorhinootologie 2002 Nov;81(11):815-819. 
82. Auclair PL, Ellis GL. Mucoepidermoid carcinoma. In: Ellis GL, Auclair PL, Gnepp DR, editors. Surgical pathology of the salivary glands. Philadelphia, PA: Saunders; 1991. p 269-298.

83. Khadaroo RG, Walton JM, Ramsay JA, Hicks MJ, Archibald SC. Mucoepidermoid carcinoma of the parotid gland: a rare presentation in a young child. J Pediatr Surg 1998 Jun;33(6): 893-895.

84. Nishimura T, Furukawa M, Kawahara E. Pleomorphic adenoma of parotid gland with cystic degeneration. J Laryngol Otol 1994 May;108(5):446-448.

85. Suh SI, Seol HY, Kim TK, Lee NJ, Kim JH, Kim KA, Woo JS, Lee JH. Acinic cell carcinoma of the head and neck: radiologicpathologic correlation. J Comput Assist Tomogr 2005 JanFeb;29(1):121-126.

86. Takeshita T, Tanaka H, Harasawa A, Kaminaga T, Imamura T, Furui S. Benign pleomorphic adenoma with extensive cystic degeneration: unusual MR findings in two cases. Radiat Med 2004 Sep-Oct;22(5):357-361.

87. Wu CW, Chi HP, Chiang FY, Hsu YC, Chan LP, Kuo WR. Giant lipoma arising from deep lobe of the parotid gland. World J Surg Oncol 2006 Jun;4:28.

88. Wong KT, Ahuja AT, King AD, Yuen EH, Yu SC. Vascular lesions of parotid gland in adult patients: diagnosis with highresolution ultrasound and MRI. Br J Radiol 2004 Jul;77(919):600-606.

89. Chong KW, Chung YF, Khoo ML, Lim DT, Hong GS, Soo KC. Management of intraparotid facial nerve schwannomas. Aust N Z J Surg 2000 Oct;70(10):732-734.

90. Hehar SS, Dugar J, Sharp J. The changing faces of a parotid mass. J Laryngol Otol 1999 Oct;113(10):938-941.

91. Oncel S, Onal K, Ermete M, Uluc E. Schwannoma (neurilemmoma) of the facial nerve presenting as a parotid mass. J Laryngol Otol 2002 Aug;116(8):642-643.

92. Chikui T, Yonetsu K, Yoshiura K, Miwa K, Kanda S, Ozeki S, Shinohara M. Imaging findings of lipomas in the orofacial region with CT, US and MRI. Oral Surg Oral Med Oral Pathol Oral Radiol Endod 1997 Jul;84(1):88-95.

93. Roebuck DJ, Ahuja AT. Hemangioendothelioma of the parotid gland in infants: sonography and correlative MR imaging. AJNR Am J Neuroradiol 2000 Jan;21(1):219-223.

94. Bruneton JN, Caramella E, Roux P, Fenart D, Manzino JJ. Comparison of ultrasonographic and histological findings for multinodular lesions of the salivary glands. Eur J Radiol 1985 Nov;5(4):295-296.

95. Goto TK, Yoshiura K, Nakayama E, Yuasa K, Tabata O, Nakano T, Kawazu T, Tanaka T, Miwa K, Shimizu M, et al. The combined use of US and MR imaging for the diagnosis of masses in the parotid region. Acta Radiol 2001 Jan;42(1):88-95.

96. Hardee PS, Carter JL, Piper KM, Ng SY. Metachronous bilateral primary adenocarcinoma of the submandibular glands. Oral Surg Oral Med Oral Pathol Oral Radiol Endod 2001 Apr;91(4): 455-461.

97. Bradley MJ, Durham LH, Lancer JM. The role of colour flow Doppler in the investigation of the salivary gland tumour. Clin Radiol 2000 Oct;55(10):759-762.

98. Eneroth CM, Hamberger CA, Jakobsson PA. Malignancy of acinic cell carcinoma. Ann Otol Rhinol Laryngol 1966 Sep;75(3):780-792.
99. Wittich GR, Scheible WF, Haget PC. Ultrasonography of the salivary glands. Radiol Clin North Am 1985 Mar;23(1):29-37.

100. Malata CM, Camilleri IG, McLean NR, Piggott TA, Soames JV. Metastatic tumours of the parotid gland. Br J Oral Maxillofac Surg 1998 Jun;36(3):190-195.

101. Pisani P, Krengli M, Ramponi A, Guglielmetti R, Pia F. Metastases to parotid gland from cancers of the upper airway and digestive tract. Br J Oral Maxillofac Surg 1998 Feb;36(1): 54-57.

102. Raut V, Sinnathuray AR, Primrose WJ. Aggressive treatment of metastasis to the parotid. Ulster Med J 2004 Nov;73(2): 85-88.

103. Seifert G, Hennign SK, Caselitz J. Metastatic tumours to the parotid and submandibular glands. Pathol Res Pract 1986 Dec;181(6):684-694.

104. Gogus C, Kilic O, Tulunay O, Tulunay O, Beduk Y. Solitary metastasis of renal cell carcinoma to the parotid gland 10 years after radical nephrectomy. Int J Urol 2004 Oct;11(10):894-896.

105. Park YW, Hlivko TJ. Parotid gland metastasis from renal cell carcinoma. Laryngoscope 2002 Mar;112(3):453-456.

106. Seijas BP, Franco FL, Sastre RM, Garcia AA, Lopez-Cedrun Cembranos JL. Metastatic renal cell carcinoma presenting as a parotid tumor. Oral Surg Oral Med Oral Pathol Oral Radiol Endod 2005 May;99(5):554-557.

107. Dunn P, Kuo TT, Shih LY, Lin TL, Wang PN, Kuo MC, Tang CC. Primary salivary gland lymphoma: a clinicopathologic study of 23 cases in Taiwan. Acta Haematol 2004;112(4):203-208.

108. Tiplady CW, Taylor PR, White J, Arullendran P, Proctor SJ; Scotland and Newcastle Lymphoma Group. Lymphoma presenting as a parotid tumour: a population-based study of diagnosis, treatment and outcome on behalf of the Scotland and Newcastle Lymphoma Group. Clin Oncol (R Coll Radiol) 2004 Sep;16(6):414-419.

109. Rodallec M, Guermazi A, Brice P, Attal P, Zagdanski AM, Frija J, de Kerviler E. Imaging of MALT lymphomas. Eur Radiol 2002 Feb;12(2):348-356.

110. Eichhorn KW, Arapakis I, Ridder GJ. Malignant non-Hodgkin's lymphoma mimicking a benign parotid tumor: sonographic findings. J Clin Ultrasound 2002 Jan;30(1):42-44.

111. Yasumoto M, Yoshimura R, Sunaba K, Shibuya H. Sonographic appearances of malignant lymphoma of the salivary glands. J Clin Ultrasound 2001 Nov-Dec;29(9):491-498.

112. Ahuja AT, Ying M, Yuen YH, Metreveli C. 'Pseudocystic' appearance of non-Hodgkin's lymphomatous nodes: an infrequent finding with high-resolution transducers. Clin Radiol 2001 Feb;56(2):111-115.

113. Giovagnorio F, Galluzzo M, Andreoli C, De Cicco ML, David $\mathrm{V}$. Color Doppler sonography in the evaluation of superficial lymphomatous lymph nodes. J Ultrasound Med 2002 Apr;21(4):403-408.

114. Kessler A, Rappaport Y, Blank A, Marmor S, Weiss J, Graif M. Cystic appearance of cervical lymph nodes is characteristic of metastatic papillary thyroid carcinoma. J Clin Ultrasound 2003 Jan;31(1):21-25.

115. Harrison LB, Zelefsky MJ, Pfister DG, Carper E, Raben A, Kraus DH, Strong EW, Rao A, Thaler H, Polyak T, et al. Detailed quality of life assessment in patients treated with primary radiotherapy for squamous cell cancer of the base of the tongue. Head Neck 1997 May;19(3):169-175. 
116. Lin A, Kim HM, Terrell JE, Dawson LA, Ship JA, Eisbruch A. Quality of life after parotid-sparing IMRT for head-and-neck cancer: a prospective longitudinal study. Int J Radiat Oncol Biol Phys 2003 Sep;57(1):61-70.

117. Buus S, Grau C, Munk OL, Bender D, Jensen K, Keiding S. 11C-methionine PET, a novel method for measuring regional salivary gland function after radiotherapy of head and neck cancer. Radiother Oncol 2004 Dec;73(3):289-296.

118. Howlett DC, Alyas F, Wong KT, Lewis K, Williams M, Moody AB, Ahuja AT. Sonographic assessment of the submandibular space. Clin Radiol 2004;59:1070-1078.

119. Nomayr A, Lell M, Sweeney R, Bautz W, Lukas P. MRI appearance of radiation-induced changes of normal cervical tissues. Eur Radiol 2001;11(9):1807-1817.

120. Capaccio P, Paglia M, Minorati D, Manzo R, Ottaviani F. Diagnosis and therapeutic management of iatrogenic parotid sialocele. Ann Otol Rhinol Laryngol 2004 Jul;113(7):562-564.

121. Gritzmann N. Sonography of the salivary glands. AJR Am J Roentgenol 1989;153:161-166.

\section{ABOUT THE AUTHORS}

\section{Rajesh C Kamble}

Head, Department of Radiology, Karuna Hospital, Jeevan Bima Nagar Borivali (West), Mumbai, Maharashtra, India

Correspondence Address: Shobha Diagnostic Centre, Shop No. 2 A Wing, Dhiraj CHSL, Poddar Road, Opp Shanti Park, Malad (East) Mumbai-400097; Shobha Diagnostic Centre, Flat No. 4, Gr. Floor Nilanajana Chsl, Marve Road, Opp. Choksi Hospital, Marve Road Malad (West), Mumbai-400064, Maharashtra, India, Phone: 9820543898, 284460606, e-mail: drrajeshkamble@gmail.com, docrajkamble@yahoo.com

\section{Alpana N Joshi}

Consultant Sonologist, Surya Children’s Hospital, Khar (West) Mumbai, Maharashtra, India

\section{Pravin J Mestry}

Consultant Sonologist, Jeevan Vikas Kendra, Andheri (East), Mumbai Maharashtra, India 